\title{
AENEAS, THE CULTURAL FATHER AND SPIRIT IN VIRGIL, DANTE AND KOTLIAREV'SKY
}

\author{
Anna Makolkin \\ University of Toronto, Canada \\ anna.makolkin@utoronto.ca
}

The purpose of this comparative analysis of the three poets separated by time, languages, ethnicity and history is to define their shared European cultural identity and continental belonging. The paper underscores Europeannes of Virgil, the Mantua, Dante, the Florentine, and Kotlliarevs'ky from Poltava whose common roots take them in the Graeco-Roman antiquity. Aeneas, the legendary Homeric character, happens to be their common cultural and poetic foundation, the "spiritual father."

The pagan Graeco-Roman past is the source of inspiration for the late Roman Virgil of Etruscan descent, Dante, the Renaissance bard, and Kotliarevs'ky, the citizen of the Russian Empire of Ukrainian origin, and they all are products of "mingling and mixing" who share European common cultural identity. If Virgil links the Etruscan and Greek past in late Rome, or Dante echoes the Latin past during the Renaissance, Kotliarevs'ky, detached from the Renaissance Europe, manages to find his kinship with Virgil and Dante via the Graeco-Roman antiquity. All the three poets ponder over cultural destinies of various people, over life and death, survival of some cultures and death of others. Acknowledging the youthfulness of his ethnic history, Kotliarevs'ky does not bemoan it, neither does he look for the impossible or non-existing roots. He has a philosophical gaze at history, celebrating reality without the traumatizing genealogical anxiety of his romantic and confused time. Instead of constructing the artificial cultural particularity, Kotliarevs'ky joins the continental discourse about remembering some and forgetting others, i.e. remembering Greece and Rome at the expense of Etruria, Phoenicia, Judea et al.

The motif of blood and kinship, the universal preoccupation of humanity, gets the analytical poetic dissection in Virgil, Dante and Kotliarevs'ky who define the meaning of Euiropeannes in mixing and mingling instead of dwelling on particularities. The Ukrainian author attaches himself to the body of European culture via antiquity. His cultural stand deviates from the Romantic ethos of glorified particularity of his day, as well as from the 20th-century future neo-Romantics, for that matter and with their general unproductive preoccupation with the imagined allegedly unique and separate collective Self.

The selected poetic triad under scrutiny also examines the gulf between the Religious and the Sacred. Religion is interpreted as a negation of true civility and reasonableness.

Key words: antiquity, pagan(ism), secular(ism), cultural identity, collective memory, cultural property, cultural lineage, symbiosis, civilized, savage, cycle, cultural mentors.

(C) Makolkin A., 2019 
Introduction. The ancient Greece and Rome, the accepted cultural progenitors of the Western civilization, stand in the collective European memory not only as the source of the collective continental pride in the achievements of the "wisest children of humanity", but as model ancient secular societies, who stood on guard against Evil without the single omnipotent God, and whose multiple deities unobtrusively accompanied man, functioning quite well on the margins. These ancient cultures also represent the European "aristocratic" cultural lineage which all the rest wish to possess, and, in this context, the myth of Aeneas embodies this universal European desire to be in communion with the Greeks and Romans. Aeneas, the legendary Homeric character, would leave the literary annals of the Greeks, becoming the migrant companion to many European folkloric traditions. For instance, the British, claiming their European "cultural nobility," would invent Brutus, the legendary founder of the British race and the alleged great grandson of the same Greek Aeneas. The British needed the mythical Brutus not only to turn them into the alleged close cultural and ethnic relatives of the Greeks and Romans, but also to prepare them for their future historical role of colonizers of the new continents. The British legendary Aeneas was the precursor of the new British Empire. In the $20^{\text {th }}$ century, D. H. Lawrence's fascination with Italy ultimately brought him to the analogous imagining of the British and the Etruscans. Each recourse of the Europeans to "their cultural childhood" would invariably bring them to the Graeco-Roman antiquity, their nostalgic place of refuge where the Aesthetic, the Rational would dominate the wildly mythical, and the secular be the sacred. The ancient Greece and Rome is the collective European shared dream, past-Desire, history-nostalgia and common cultural pathway.

Our glimpse at the poetic migration of the myth of Aeneas in Virgil (70BC-19BC), Dante (1265-1321) and Ivan Kotliarevs'ky (1769-1838) will attempt to demonstrate this dream in another context. We shall also show how poetic reinventions of history challenge the eternally biased and politicized historiography. Virgil turned to Troy and Homer for the spiritual comfort of the Augustian Rome, anticipating the birth of monotheism and the long tyranny of the Judeo-Christian mythology. Dante, the witness of the spiritual and cultural regress of the descendants of the Graeco-Roman culture, would resurrect Virgil in order to pass the judgement on the historical detours of the Europeans, victimized by the mythology of the conquered shepherds in the Middle East. In anticipation of the Renaissance and recourse to antiquity, Dante would mourn Rome that had exchanged the pagan poetic wisdom of Virgil for the sacred didacticism of the Bible. The "Ukrainian Virgil," loyal to the Russian Empire and the European Enlightenment, Ivan Kotliarevs'ky would try to repossess Aeneas in order to establish the same kinship with the same cultural ancestors, with the purpose of including the Russians and Ukrainians into Europe. If Virgil "sings to arms and men", Dante- to Poetry, Kotliarevs'ky invites to drink the elixir of the Rableasian laughter over the foolishness of man who takes overly seriously one's own past and history. The three poets - Virgil, Dante and Kotliarevs'ky - collectively rewrite the history of Europe from the battle of Troy, to the Augustian Rome, recalling the resettlements near Cumae/Naples, the foundation of Rome, the 
rise and fall of the Roman Empire, the absorption of the Judeans and Christians, and next the tyranny of the Christian Church and the pagan revival during the pre-Renaissance, finalized by the judgement of the Enlightenment from the European margins. Aeneas, repossessed by the Italians and the Slavs, signifies the steady parallel cultural line, the Hellenic versus Hebraic legacy which persistently haunted all Europeans, challenging the cultural detours. The poetic triad under scrutiny leads one from $1180 \mathrm{BC}$ to the $1800 \mathrm{AD}$, engaging the readers into the ongoing cultural debate about the usefulness of the monotheistic mythology and its impact upon the status of Culture and Civilization through the ages.

\section{Virgil, the Chronicler of the Graeco-Roman Past}

\section{2. The Road from Troy to Rome via the Mythical Hesperia}

"It is so hard to found the race of Rome," admits Virgil at the very beginning of his poetic history of the Roman Empire. His task was to "dignify a state whose dignity was new" [4, p. 201]. Virgil completed his eleven-year labor on the Aeneid in the $19^{\text {th }} \mathrm{BC}$, at the dawn of the Augustian Rome, which required a strong historiographic, mythopoetic and poeticorhetorical foundation to assert its new cultural identity. It would though be too simplistic to reduce Virgil's work to the jingoistic artistic service to the benevolent Emperor Augustus. After all, the attempts to tell the story of the Graeco- Roman cultural relatedness had been made even prior to Virgil. The impact of the ancient Hellenic philosophy, literature and art had been acknowledged by most Romans, by their colonized Europeans, Asians and Africans. The stories about the ancient Greek, Trojan, Phoenician and Etrusco-Roman cultural symbiosis, the Arcadian settlements and migrations to the shores of Ausonia, were abundant even prior to Virgil, both in Greek and Latin. Cicero's (106-43 BC) friend Scaevola wrote in Greek; Theocritus, Euclius, and Philodermos also had direct impact on Virgil. Phylodermos was a pupil of Zeno at Athens, and Parthenius who tutored Virgil in Greek, while he lived in Naples, must have introduced him to most of the poets and philosophers of the Alexandrian school. Naples itself, founded from the settlement of Cumae about 600BC, was the centre of the Greek civilization even after the Romans would colonize it in 327BC [4, p. 26).

The Greek philosophy, drama, poetry and mythology nurtured and sustained the curious, receptive and culture-thirsty Romans. It was not enough, however, for the anxious Roman Empire to admit the Greek cultural mentorship. The cultural belonging was not convincing enough, they desired the ethnic, blood kinship for the adequate status in the cultural heroic pantheon. Rome, indeed, needed his Homer, but Virgil provided more - he poetically traced the alleged blood origins of Ausonia to Arcadia, tying the ancient Peloponnesus and Troy to Rome, Priam and Apollo, Helen and Agamemnon, Aeneas and Venus to Lavinia, Silvius, Romulus and Remus. Virgil gave a mythical but desired blood lineage, which connected the ancient Greeks, Trojans and their descendants to Ausonians, the Roman ancestors. His Aeneid proclaimed that "in time to come, with turning years, the Romans will be born and, from the resurrected blood of Teucer, rise up as rulers over sea and land" [20, Book 1, p. 9].

Teucer, the alleged ancient king of Troy whose domain was Teucria, symbolized the ancient glory of the Troyad, the kingdom in the Asia Manor, at the entrance of Dardanelles, destroyed around $1180 \mathrm{BC}$. This Hellenic prehistory would enter the Greek heroic pantheon. But the Trojans, as we learn from Virgil, differed racially from the Hellenic tribe. The motif 
of mingling of the races either through voyage, exile, war, or treaty is prominent in his epic. Virgil stresses that "fates made the worlds of Europe and Asia clash' despite the Gods' disinclination to allow such a mingling [20, p. 170]. The ocean knows more about the secrets and outcomes of voyages, whose eternal companion and ruler was Venus, the underlying cause of wars, misery and suffering for numerous people, but also the force behind the successful union of different nations, races and religions - New Troy, New Carthage and Rome: "I have splashed the Trojans with Ausonian blood [20, Book 7, p. 180]; "Both our races branch out of one blood" [20, Book 7, p. 170].

The mythical Evander, the son of Mercury and Carmentis, the ruler of Arcadia and the alleged founder of a colony for his exiled countrymen on the banks of Tiber- the Pallantium, speaks to us through the ages, delivering the story of the Graeco-Roman union: "These groves were once the home of fauns and nymphs and of a race of men sprung free trunks. They had no rule and no refinements; for they could not yoke their bulls, or gather wealth, or save what they had gained. They fed on branches and hash food of hunters. Then Saturn came to them from high Olympus, a fugitive from his lost kingdom, flying from the attack of Jove. He made nation of those untamed and scattered in high mountains and gave them their laws. And he chose Latium as name. Then came Ausonians, Sicanians" [20, Book 8, p. 201].

Virgil poetically acknowledges the civilizing efforts of the ancient Greek settlers on the territory of the future Italy, their role in making a new state out of the scattered people.

Virgil Publius Maro (70 BC-19 BC), born near Mantua, the alleged son of an Etruscan pottery family, not only does not reject his own proud roots but he also reminds the Romans about another branch of their less popularized legacy - the mystical extinct Etruscans, silently glaring from the numerous murals of the monumental mines, out of whose bones and ashes sprang up the new Latin race: "O Mantua, you are the capital of peoples, rising from three races each, the rulers of four towns; but you yourself have drawn your chief strength from your Tuscan blood" [20, BX, p. 250].

Tuscan is the symbol of the Etruscan, Lydian, Maeonian and Tyrrhenian, the mysterious ancestors, who had bequeathed to the Romans their remarkable art, civic functional spaces, roads, bridges and aqueducts, but who would be destined to disappear mysteriously from their cultural memory. Nikolay Mashkin reported that the Etruscan language seized to exist in the I BC [13, p. 74-77]. Till this day, the Etruscan script, akin to the Greek and Phoenician, having originated in $7^{\text {th }}$ century $\mathrm{BC}$, continues to intrigue the linguists, having preserved still undeciphered messages in the unknown tongue. Why have they been made extinct? Why had most of the written monuments of these proto-Romans been destroyed while the alleged legacy of the conquered primitive Judea would be transmitted through the ages? Apparently, the Hebrew shepherds, having neither art, nor music, represented no imaginable cultural threat while the powerful, inventive, creative and artistic Etruscans did. Virgil portrays them as skillful fighters, battling for the Ausonian paradise, the allies of Aeneas. What strikes is the Biblical analogy. Tarchon, an Etruscan, chief of Agylla (now Cerveteri), the centre of the religious worship, near the North West of Rome, addresses his soldiers "as my chosen ones." Tarchon was the ally of Aeneas when the troops of Troy and Latium clashed. The new Roman race was conceived in the bloody battles for each inch of the "promised land." The tranquil refuge from the Trojans, Hesperia, and the Lydians 
is Tiber where "all the tribes of Italy and all Oenotria seek answers in uncertainty," where the days of gladness lie in wait" for a kingdom and a royal bridge". They turn out to be the hell through which Virgil takes Aeneas to crush the ferocious old nations and to establish a new way of life and walls for his own people [20, Book 1, p. 10]. The ordeal of murder when his allies - the Etruscans, Dardons, Ligurians, Phyrigians - are mercilessly destroyed, is another historical storm, the military baptism of the new nation and race, born out of the wedlock of battles, death and victory, another tide in the historical sea and another cycle of colonizing, appropriating the past and the cultural property of the colonized. Virgil's poetic history of Rome anticipates by more than a millennium the Neapolitan philosopher, Giambattista Vico, whose cyclicity model would be later revived in the $19^{\text {th }}$ and $20^{\text {th }}$ century romantic history - by Marx, Engels and Lenin, by the Frankfurt school of sociologists, by Sartre, Foucault and Marcuse.

Virgil accepted force as an evil necessity, an angry outburst of Fate, but he also lamented the lack of the existential wisdom in the struggle for conquest, power and domination. Speaking through Jove/Jupiter, Virgil appealed to human Reason: "Great sons of heaven, why this shift in plan, this bickering with belligerence? I ordered Italy to leave the Trojans untouched; why quarrel, then against my will? What I want: a league of peace" [20, BX, p. 244].

Virgil's poetic defense of the victimized Troy, a prominent trope in the epic, defies the standard view about his blind devotion to the Roman Emperor. The poet apparently abhorred the horrors of the battle, the tragic consequences of war, defending its victims and the non-aggressive behavior of the less belligerent tribes. His Trojans were simply "unhappy wanderers", carried by the winds across the seas", a pious, a defeated race, "who did not have violence on their minds." They too sought refuge in the land of the desired Hesperia. This was a poetical racial history of the Romans, who had embraced various people on their journey of becoming an Empire. It is remarkable that the ancient mythically expressed history of Rome excluded the Phoenicians and other exotic oriental relatives from this peculiar hagiography.

Virgil, the advocate of mingling in general, protected his hero Aeneas from the temptations of the Phoenician seductress Dido. He made him reject her eager help, the wealth and ammunition of the Tyrian/Phoenician kingdom. Tyre, appearing in the Bible next to Alexandria and Spain, remained as a puzzling connection between the Judeo-Christian monotheistic world and the Graeco-Roman polytheistic cultural universe. In fact, Tyre, the cultural foundation of the Graeco-Roman world, had been also made obscure [12]. Virgil defends not so much the racial, but the cultural historic formula, by his including the Etruscans in the poetic history of Rome and marginalizing the Phoenitians or Libyans. Virgil's race is a strain of the powerful, curious and persistent people, who are eager to migrate far to found a new kingdom of Law, Order, Peace and Love, asserting themselves "through their acts," and "burning to know, to ask the reasons" [20, Book 2, p. 33). He sings the ode not only to Arms, but to human Energy and Creativity, that "prolongs one's fame by acts" [20, BX, p. 259]. The Latin poet of the Etruscan origin empathizes with the "sorrowful Phoenicians and mourning Trojans, but Fate and Gods are on guard for the purposeful, courageous builders of the Latium, the creators of the promised mythical Hesperia. 


\subsection{Virgil's Contradictions}

Virgil begins his epic with the assured panegyrical lines to his victorious age: "I sing of arms and of a man. His fate had made him fugitive" which already hold contradictions. His song to strength and courage is also a lament over the Tragic Human Fate, forcing one to flee one's home and become a refugee in a foreign land. The motif of glorification of battle and force is intertwined with the less prominent sorrow over the unnecessary suffering of man, the tragedy of exile. Good and Evil, force and meditation, power and weakness, victory and defeat are sculpted in Virgil's poetic monument to the Graeco-Roman past. The victorious conquest has the other tragic side - it bears the pain of the conquered, and this other side of the epic undermines the canonical genre of a heroic panegyric to the new Mediterranean rulers, offering a contemplation on the existential consequences of conquest. Virgil, paying tribute to his cultural relatives, the ancient Greeks, is drawn to tragedy, and his hero - Aeneas is partly a tragic figure [1]. His tragedy lies in the awareness of the harm, inflicted by man on the road to military and political success, the evil of Arms and Ambition. As much as Virgil is in awe of the daring conquests, which ultimately made Rome, he is also saddened by the needless death and destruction of the ancient civilizations, ancient allies, such as Etruscans. After all, he is an Etruscan from Mantua. His Aeneid is a poetic monument to the early Romans and their proud civilized relatives, the Etruscans, who had perished without words left, whose language, the most powerful and dangerous weapon, had been erased even from most stones. The Etruscans were left to stare silently at their numerous future descendants with their pottery and painted murals. Their gods and rituals, songs and poems, messages and images had been sacrificed, as it would appear later, for the sake of the future, less threatening mythologies and monotheistic systems. Virgil laments about the peaceful imagined serene Ausonia, the desired refuge and the promised land for the Greek refugees which turned into another armed battle. Virgil sings of arms and armed men, but also of peace: "Join hands in treaty"[20, BXT, p. 284]; "O Latins, how I wish we could have settled this mighty matter earlier: that would have been than debating now with Trojans at our walls. My citizens, we wage a luckless war against the nation of Gods, unconquered men: no battle can exhaust them" [20, BXL, p. 285].

The wisdom of a peaceful reconciliation with the enemies is voiced by Drances, who opposes war and offers to give up the territory, inhabited by Sicanians, Auruncans and Rutulians, "passing it on Teucrians in friendship" and in exchange for peace. The preJudeo-Christian existential wisdom is in the words of Drances, who proposes to lay down the swords for the sake of lawful behavior and the end of violence. Virgil, a witness of the grand conquests of Caesar in Britain, Africa, Greece and Spain, actually allows himself a certain critique of colonial politics, entrenched in bloody violence and destruction.

The Savage versus Civilized is a subtle motif of his analytical introspection, which deviates from the general theme of the pro-Homerian epic. Mezentius, the king of the Etruscans, dies at the hands of the "savage Trojan": "You, savage one, why try to frighten me?"[20, BX, p. 272].

Virgil's historical Self anticipates the future Gibbon's organic model of history. He obviously sees the rise and fall of the decaying civilizations, doomed to oblivion under the violent attack of the brutal newcomers. Thus, Virgil accepts that in history "Each has his day; 
there is, for all, a short irreparable time of life; the task of courage: to prolong one's fame by acts" [20, BX, p. 259].

All had their day - the Etruscans, the Trojans, the Phoenicians, Libyans, Sarmatians, Sicanians, Rutulians, and all had passed through the cycles of heroic barbarism, the ages of swords, the periods of civilized living and heights of creativity, the rise of Arts and Letters, the blooming of Thought and Logos. Virgil was a great mentor to the future Giambattista Vico, the Neapolitan thinker of the Enlightenment and his most illustrious pupil, who would resurrect on site of the ancient Greek colonies the wisdom of his Drances, the civilizing antithesis to the Roman conquerors. The intended Imperial epic is subverted by the Virgilian artistic loyalty to authenticity and poetic biographies of the Roman ancestors. Even accepting the inevitability of the cycle of the sword, sweeping away the legacy of the pious, nonbelligerent Other, Virgil, the poetic chronicler of the Roman history, is dismayed by the barbarism of Conquest and its tragic human cost. Perhaps, this was the reason why Virgil had refused to share his epic with Augustus, his old friend, confidant, admirer and patron of his Muse. Eventually, Augustus would read only three books of the Aeneid - the second, on the fall of Troy, the fourth, on the death of Dido, and "the sixth about the underworld" [4, p. 123].

\subsection{The Other Aeneids}

The story of Aeneas attracted also Stesichore in $6^{\text {th }}$ century BC, Licofione $\left(3^{\text {rd }}\right.$ cent. $\mathrm{BC})$, Avieno ( $4^{\text {th }}$ cent. BC) and Fulgenzio $\left(5^{\text {th }}\right.$ cent. BC). Peter Levi reports that" long before Virgil's time, Aeneas was being hailed as the forefather of the whole Roman race" [4, p. 126]. Lucretius wrote "Aenneadum genetrix" about Venus, the mother of the children of Aeneas. Caesar founded a temple of Venus Genetrix, immortalizing Aenaeus, as the great Roman ancestor. Ennius recreated Venus as "genetrix patrius nostri". The title "Aeneadum genetrix" was even found on the wall of Pompeii [4, p. 127]. To reinforce the power of the Romans, it was not sufficient to proclaim their indebtedness to the Hellenic culture, it was necessary to obtain the mythical genealogy, constructing the poetic evidence of blood kinship. For that purpose, it was necessary to transplant Troy onto the Roman soil - Ostia was the New Troy [4]. The Augustian Rome needed new historiography and, prior to that, a new supportive poetic narrative, the indispensable cultural foundation. It is endemic for history to adjust its narrative to the political aims of the moment through the poetic capital. To elevate the Romans by building their supportive grand historiographic myth, it was crucial to expunge from the collective memory the ghosts of the Rutulians, Etruscans, Phrygians, Samnites, Illyrians and Thracians, among others, showing their marginal role in the history of the New invincible Troy - Rome. The fall of the Etruscan civilization, not marginal in the history of the Roman Empire and history of Italy, had to be symbolically relived. To erase their collective history, one had to start burying their past on the eve of the inception of the New Troy, New Carthage, and the cultural transplantation in the "neapolis" - Naples. Virgil had to engage into the poetic debate with the interpreters of the past, defying the earlier myths and superimposing them on his own, more suitable for the Augustian Roman history. 


\section{History as Comedy of Divine Errors}

\subsection{Dante's Torch Through the Woods of History}

Nearly fourteen centuries after Virgil's "Aeneid", at the dawn of the European Renaissance, and during another cultural rise in the Italian history, Dante Alighieri (1265-1321) undertook another huge task of poetic rewriting of history. Not a stranger to the Florentine/Roman politics, a refugee from the war between the Blacks and the Whites, a victim of the political reprisals and wanderer over the land of the ancient Etruscans, refugees from Troy and Tyre, Dante dreamt about another rebirth of the idyllic Virgil's Ausonia. If Virgil had to connect the twelve centuries of the pagan times, Dante's analogous effort is somewhat more complicated. Dante had to bring his contemporaries to the dawn of the Renaissance from the pagan Roman and Christian past, tying together the Hellenic, Hebraic and Roman heritage, the already distant mythical Greece, Troy, Carthage/New Tyre, Jerusalem, Alexandria, Rome of the Augustus and Constantine, and the Christian Rome, known to his contemporaries in Florence and Pisa, Genoa and Naples, Venice and Milan, overseen by the Pope. Dante was bom into the family of Guelphs, the Florentine faction which supported the Church [Machiavelli, p. 27). Nonetheless, the pagan Virgil, his guide though his Inferno, the imagined hell for the Christian sinners, confesses: "Non omo, omo gia fui, e li parenti miei furon lombardi, mantovani per patria ambedui. Nacqui sub Julio, ancor che fosse tardi, e vissi a Roma sotto'l buono Augosto nel tempo de li d'ei falsi e bugiardi. Poeta fui, e cantai di quel giusto figlinol d'Anchese che venne di Troya" [18, Canto 1, p. 6].

Virgil, a poet and a pagan sage, forges a link between the mythical Troy, Troyan exiles, the Etruscan reign of Mantua, the Augustian reign of Rome and the Dantean Florence. Understanding the ambition of his own task, Dante shares his historical anxiety, making Virgil ask Dante at the gates of Christian hell: "Ma tu perche ritomi a tante noia?" [Ibid.].

Dante has to make recourse to the very ancient history in order to reconstruct the united mythical pathway from the fall of Troy in $1180 \mathrm{BC}$ to the $13^{\text {th }}$ century AD. He is a Christian poet, but whose master and mentor is Virgil, a wise pagan. His artistic self is the embodiment of the human creative spirit, overcoming the challenge of the religious ambiguity. If Virgil sings of "arms and men," Dante poetically holds the entire humanity responsible for the alleged cultural detours, the diversion from the civilized journey into the world of Poetry, Art, Love, Dream, Song and Dance: "Nel mezzo del cammin di nostra vita mi ritrovai per una selva osuera" [18, Canto 1, p. 2].

I would like to challenge the traditional interpreters of this allegory who understood it in the Biblical, New Testament terms (Silverstein; Augustine; Singleton). One may rather perceive the Dantean "nostra vita" not as a condemned post-Judeo-Christian community who had deviated from the moral pathway, the post-Graeco-Roman civilization at the crossroads, forced by the monotheism to forget its pagan humanistic past, and pressured by the controlling Church into a different cultural paradigm:

$\begin{array}{ll}\text { FALL OF TROY BC } & \text { EVE OF THE RENAISSANCE } \\ 1180 \mathrm{BC} & 1300 \mathrm{AD} \\ \text { ROME } & \text { ITALY } \\ \text { POLYTHEISTIC } & \text { MONOTHEISTIC } \\ \text { EVOLVING } & \text { SUPPRESSED }\end{array}$


"Selva oscura" could be read as the image of the monotheistic darkness and of the Church tyranny, into which the formerly free thinking Graeco-Romans plunged, having lost their "il ben de intelletto'/the good of intellect [18, Canto 111, p. 24]. On his journey to Light, in search for the lost intellect, Dante seeks Virgil's help, the allegorical plea for (c'hanno perduto) the lost compass of cultural and artistic development, guiding and delighting humans on their journey through life.

\subsection{Mocking the Divine}

Dante's Divine Comedy is equally a poetic condemnation of blind Belief and a mockery of the Irrational and poetic rewriting of the European cultural history. He allegorically judges Emperor Constantine for reversing the course of the Roman civilization, by having transferred the seat of the Empire from Rome to Byzantium [18, Paradiso, Canto VI, p. 58]. Dante argues that, at the moment of adoption of Christianity, the time clock of the European civilization had been set back. The ancient Hellenic past had been betrayed in favor of the new single omnipotent Deity, with freedom and democracy being sacrificed for the tyranny of the Christian Church. The free man/liber uomo got caught between the monotheistic schism and the Judeo-Christian mire. His "ferocious wolves/'fieri lupi embody the institutional fanatics of Judaism and Christianity, who would keep the European rational and civilized man away from the authentic Art, Poetry, Thought and Music for centuries. The mythical Beatrice in Paradiso reminds that "reason's wings are short/lar ragione ha corte Tali and that Faith is needed when Reason fails [18, Canto II, p. 18]. Dante's deistic universe revolves around the Greek pantheon of Apollo and Parnassus. He regards the eleven centuries since the adoption of Christianity as a regrettable gap in the development of the descendants of Troy and their civilization, who had deviated from the originally intended course. The Hellenic past and free thinking had been allegedly surrendered to the dogmatic myth of the Hebrews and their Christian quarreling spiritual relatives: Dante's "Paradiso" is the celestial Athens, among the planets of Saturn, Mars and Jupiter, the place where the Phoenician, Hellenic, and Roman ancestral heroes meet, dreaming about freedom and life, void of the monotheistic tyranny. Dante introduces a mythical free man, unbaptized, innocent of monotheism, and yet caring, ethical, thinking and quite reasonable: 'Un uom nasce a la' riva de 'Indo, quievi non e' chi ragion, di Christo ne' chi legga ne chi scriva, e tutti suoi voleri e alti buoni sono, quanto ragione umana vede, sanza peccato in vita o in sermoni, muore non battezzato e sanza fede: Ov'e' questa giustizia che'l condanna ov e la colpa sua,se ei non crede?" [18, Paradiso, Canto XIX, p. 212].

The Dantean "Paradise" paradoxically includes the secular world without Christ, populated by the people who are able to live and die without faith in the Divine Father/Holy Spirit and son. After all, it is possible to act honorably without the sermon, the fear of God's punishment, without the Christian ritual, but with the recourse to the human law, the Roman code, developed and outlined before the adoption of Christianity. Apparently, the debate between the followers of Christ and the spiritually unattached Graeco-Romans was still quite intense in Dante's time. The discussion about the role of the priests and secular rulers enters "The Divine Comedy" not accidentally. Dante, himself, a refugee from the Florentine war between the pro-Church Guelphs and the secular Ghibellines, was reliving in his epic the 
agony of the religious conflict. Niccolo Machiavelli would rebroadcast this tormenting episode in the Roman and Italian history in his "The History of Florence". Trying to hypothesize about the causes of the fall of the Roman Empire, Machiavelli would bring into focus this Dantean view and express the apparently then predominant collective regret over the fatal relocation since Constantine - from Rome to Constantinople. This echo of the Dantean crucial motif in Machiavelli alludes to the now neglected but, perhaps, prominent during the Renaissance, the anti-Judeo-Christian ethos and stand on the historic shift of civilization since the adoption of Christianity. Dante's metaphoric and allegoric condemnation of the Hebraic legacy - Christianity, would later inspire Machiavelli to state his own political diagnosis of the Roman decay. According to Machiavelli, the Emperor Constantine "had actually set the course of the destruction of the Roman Empire by having become a Christian" [5, p. 12-13]. Both Dante and Machiavelli mourned not only the destruction of the Roman Empire as a political entity, but its cultural defeat, imposed by the adoption of monotheism and construction of the secondary powerful political institution in society. Since the adoption of Christianity, Church would become the culturally and politically restraining force, a barrier to the development of the pagan Graeco-Roman civilization.

Dante's Christians are "miseri lassi"/"wretched creatures", whose sick mentality/lavista de "la mente infermi," shaped by the central anti-existential religious myth, paralyzes their innate vitality, making them unable to enjoy life and paradise on Earth, turning them into passive, fearful, and dull beings, deprived of their artistic imagination and adequate reasoning. Having embraced the dogma of the wandering shepherds from Judea, the descendants of Venus and Apollo, Saturn and Jupiter, Troy and Mars have been taken hostage by the gray, depressing myth, depriving of the healthy and happy NOW, designed by poets and sages. The ideological conflict between the settled cultivators of the fertile land on the shores of the Adriatic, Ligurian and Tyrrhenian seas, and the original nomads from the Red sea reaches its climax. Did the inheritors of Pythagoras and Homer, Plato and Aristotle, Virgil and Aristophanes, Sappho and Zeno need the martyrdom of Christ? Weren't they able to judge, govern and exist without the leap into the fantastic mythology of a less developed society? The Judeo-Christian saga since 66 Ad till 333 was presented by Dante as a barbarous dark period in the history of the Romans and Italians, as well as all Europeans.

\subsection{Redeeming the Pagans}

Although hell is the proper place for the Christian infidels, Dante challenges God by defending not only the pagans "ch'ei non peccaro" / "who did not sin", but those who "had not even been baptized"/ "non ebber battesmo". Here, in the blasphemous Canto ID, the future Italian national poet allegorically questions the meaning of the Christian communion, since even Augustine, on whom Dante relies, admitted that noble deeds were possible even without belief in a single Christian God. In the very irreverent Canto, Dante poetically judges the usefulness of the Hebrew sacred heroes, such as Moses, the giver of laws, Abraham, the patriarch or David, the king, and the prophets. Several centuries later, Montesquieu would commend the Pappian law, augmented by Tiberius and many aspects of the Roman law, regarding the monogamous family and women's rights, echoing Dante and Machiavelli, and 
reviving the expunged debate about the need of Christianity $[9$, p. 74). He would argue that the advanced and sophisticated Roman family law had been far superior to the dogmatism of the ancient Hebrews and their mythological narrative. Moreover, Montesquieu, one of the apostles the Enlightenment, would bring to life the Dantean thesis about the overriding power of the human intellect, defeated by the tyrannical monotheism. The adoption of Christianity, the offshoot of Judaism, was viewed by Dante and apparently, by the cultural elite of his day, as a digression from the civilized Graeco-Roman pathway. After all, the descendants of Plato and Aristotle, Euripides and Sappho, Pythagoras and Varro, Aristophanes and Suetonius, Zeno and Plutarch, Hesiod and Horace among others did not benefit from the cultural invasion of the Hebrew shepherds. The intellectually, aesthetically, artistically, economically, socially and legally superior Roman civilization, forged out of the melange of different races and sophisticated cultures, had deviated from its own developmental pathway by stepping into the murky universe of the naive Hebrew mythologizers of the already interpreted world. David and Noah, Moses and Abraham, and the entire Hebraic pantheon are in Dantean Inferno, through which he and his readers are led by Virgil, the Sage and Poet, honoring "scienzia e arte"/"science and art", Reason and Analysis, and questioning Belief and blind Obedience, submission to the imposed monotheistic cult. The new monotheistic religion, appealing to the uneducated masses, suffocated the Romans who would eventually surrender their Law, Ethics, Art and Reasoning to the delusional state of the uneducated majority, seduced by the mythical byproduct of the colonized Judeans. The Christian God, punishing the scientist and artist, is a questionable cultural artifact, and Virgil, Dante's poetic mentor and spiritual guide, is called upon from the annals of the antiquity to help Dante and his contemporaries to leave the "woods" of prejudice, darkness and obscurantism. Dante draws the distinction between the "lawless shepherds," the barbarians of the Mediterranean region and his own ancestors: "Considerate la vostra semenza; fatti non foste a viver come bruti, ma per sequer virtute e canoscenza" [18, Canto XXVL, p. 278].

To those who pride themselves in the new Judeo-Christian ethics, Dante reminds of Aristotle and his Ethics, allegedly surpassing in sophistication the anonymous authors of the Biblical Ten Commandments. Any uncritical acceptance of authority is repulsive to Dante who wishes to bum all idolaters, who insist on the restricting paradigm of either one god, or many/se non ch'elli uno, e voi ne orrate cento - the Hebraic or Graeco-Roman. He condemns Constantine for forcing Christianity - the rewritten Judaism - onto the imaginative sons of Aeneas, the descendants of the Etruscans and Trojans, Phoenicians and Sicanians, the children of Venus and worshipers of Zeus: "Ahi,Constantin,di quanto mal fu madre, non la tua conversion,ma quella dite che da te prese il primo ricco patre!"

Dante predicts in his $19^{\text {th }}$ Cnato that a new Jason will come to root out the Hebraic religion, reinstalling the Greek customs and Roman law. The tour through the Inferno with the Poet Laureate has a special revisionist purpose. Dante laments the unnecessary woes of the people, who had succumbed to blind Belief and domination of the new hypocrites [8, p. 72-74]. His recourse to the Greek mythology in the Divine Comedy overpowers the references to the Bible. Being himself a product and a victim of the religious schism, Dante looks back in anger at the civilized Romans who deviated from their civilized laws, imaginative art and science by adopting the Judeo-Christian fearful code of the obedient 
shepherds. This anger and lament are placed in the subtext of his general narrative, avoided by the numerous commentators from the Middle Ages up to the modem secular age.

\subsection{Making Man Divine}

Uomo liber/free man occupies the central place in the highly allegorical The Divine Comedy, and he is the addressee of Dante's exalted and passionate poetic appeals and questions: "Perchi l'animo tuo tanto s'impiglia?" (Why your mind/soul so entangled) [18, Purgatorio, Canto V]. Dante's only spiritual father is Virgil, the true god of poetry, whose divine poetic flame/ la divina flamma is both la mamma fummi,e fummi nutrice/mother and nurse [Purgatorio, Canto XXI, p. 230].

Dante dethrones the divine Christianity and even the Hellenic heroic dozen in favor of Poet-god and the creative "homo sapiens". This image anticipates the Carlylean heroic typology by six centuries [6]. Anticipating the arrival of the Renaissance and the Enlightenment by four centuries, Dante worships Reason. He forgives human steps backward, the leap into monotheism and the fanatical Judeo-Christian conflict. Firmly believing in Reason and recovery from a blind Belief, Dante urges man to overcome weakness and undertake a new cycle of human exploration, just as in the past: "Quante volte, del tempo che rimembre, legge, moneta, officio e costume hai tu mutato, e rinovato membre!' [18, Purgatorio, Canto VI, p. 64].

It is only human to evolve, changing laws and customs, tongues and costumes, tunesand ideas. The title of his immortal work reveals that the adoption of Christianity by "servile Italy" was just another theatrical social play, a change of costumes, and "commedia," staged by the playful children of the Romans, in the eternal spirit of change and performance. Dante urges his readers to remember the Etruscan/Mantoan past by excavating the courageous civilized Roman, uninhibited by the dogmatic new faith: "O Mantoano, io son Sordello! Della tua terra" [18, Purgatorio, CantoVI, p. 58].

It is not in vain that Dante "arranges" the meeting of the two Mantuans- Sordello, the $12^{\text {th }}$ century Provencal poet, born near Mantua, and Virgil, also a Mantuan. Mantua and Etruria embody the nostalgic time of human authenticity, artistic freedom, and the cultural legendary roots of Italians and all Europeans. Instead of the love for Christ, Dante worships the love between man and woman, and Beatrice, his beloved, epitomizes human intelligence and the right pathway on journey through life. Woman/donna/femmina is the chief Goddess and the only worthy object of Love, the truly divine and most powerful force - "l'amor che move il sole e l'altre stele"/"that moves the sun and other stars." It is Beatrice who shows the way to human recovery from the religious malaise. It is the Goddess of Love that holds the key to existence Here and Now, under the sun and stars. The Dantean genuine paradise is open to all human beings, who follow their Reason and Love, acting nobly and honorably without the Christian sermon and baptism, without the sacrifice of pleasure, art, music and beauty. Dante's poetic protest paves the way to the Renaissance and resurrection of the Graeco-Roman cultural organizing principle. The Dantean happy man is the thinking being of antiquity, the Aristotelian man, able to reflect upon one's own wrongdoings as well as cure oneself from the tyranny of the religious paradigm and intellectual trauma, inflicted by the Hebraico/Christian legacy. Centuries after Virgil, Dante returns to the Western Man his ancient cultural property - his culturally complex, mingled and intertwined past, molded by 
the Phoenician and Etruscan, Trojan and Hellenic, Illyrian and Roman, Cretan and Cypriot legacies, confiscated by the Christian church and the Judeo-Christian dogma. He predicted the day when all Europeans may become one, when Portugal, Norway, Scotland, Cyprus, and Hungary might compete in wealth and independence with Venice (Paradiso, Canto XIX). His Ode to Man is the prelude to the cycle of the glorious Renaissance and the cycle of free and liberating human imagination.

\section{Kotliarevs'ky's Comic Genealogy of Ukrainians}

\section{1. Anticipating the New Carthage by the Black Sea}

During the rise of the Russian Empire, in the midst of the exploration of the New Russia by the Black sea, Ivan Kotliarevs'ky, a native of Poltava, Ukraine (1769-1838), makes another poetic recourse to the very antiquity, tackled by Dante and Virgil. It comes after the similar attempts by Aldobrando di Cerretani (1560), Iohanne Schmidt (1730), Aloys Blumauer (1771), Giambattista Lalli (1633), Paul De Scarron (1660), Brebeauf (1661), Folenchio (1517), Pietro Metastacio and Nikolay Osipov (1790) [2; 14; 16]. The intention of his politicoanthropological farce, filled with poignant irony and irresistible laughter, goes far beyond a trivial parody of Graeco-Roman Aeneas, transplanted onto the Slavic cultural universe. On the eve of founding the New Arcadia by the Black Sea (port of Odessa, in 1794), destined to become the Slavic Carthage and mini Rome, Kotliarevs'ky muses about the Graeco-Roman origins of the Western civilization and the eternal cyclicity of the cultural tides. Empires fall and rise again. Migrating warriors, like Aeneas, may never find happiness for themselves, but theirs is the mission of transplanting and transforming Culture. If Virgil's Aeneas connected Troy, Athens and Rome, Kotliarevs'ky's Aeneas, in a Turkish attire, indulging in the Ukrainian gastronomy, is a later cultural envoy, an offspring of many previous civilizations, the energetic byproduct of the mingling races, the primary beneficiary of the existential wisdom of Venus and other pagan deities. The Ukrainian Aeneas possesses the historical memory, going back to Etruria and Cumae, Troy and Rome, Cyprus and Crete, Tyre, and New Tyre - Carthage, and Jerusalem. He embraces the pagan, pre- and Graeco-Roman antiquity, the Judeo-Christian, Western and Eastern European complicated past. On the eve of the Napoleonic fiasco, the Russian successful cultural leap through the Enlightenment into the European Romantic cultural parade, the former Russian tzarist military officer undertakes a poetic memoir about the European conquest through the ages.

Like Virgil, Kotliarevs'ky sings his ode to arms and men, but even more so to human survival and enjoyment of life, despite the odds of wars and brutality of colonizations. He is not so much preoccupied with the power of the Russian Empire as he is concerned with the advantages of peace and the prospects for the new Eastern European civilization. The Ukrainian $18^{\text {th }}$ century poet evens out the line of the European civilization, drawing a map where one finds the ancient Troy, Rome, Carthage and St Petersburg, Kyiv, Poltava and the future Odessa - all bound by one continent and the common European past. Observing the rise of the new Eastern European civilization on the outskirts of the old continent, Kotliarevs'ky treads a well-trodden poetic pathway. Aware of the deficiencies of a younger Slavic European civilization, the poet still pays tribute to the Greeks, Romans, Egyptians, Phoenicians, Babylonians and Hebrews, trying to extend the family of the European cultural 
relatives. The former military man brings to the Slavic "Aeneid" his knowledge of the ultimate goals of conquest - the absorption and assimilation of the defeated. Having completed his work prior to the Russian victories over the Turks, their rising influence after the Black sea explorations and foreign colonizations, the poet introduces Russia and Ukraine to the rest of Europe, as a new cultural and political ally. Kotliarevs'ky reminds his Slavic readers that "the Latin and the Trojan tribes used to be like close kin", and the mission of their younger Slavic European relatives is to preserve the Greaco-Roman legacy, "their name, language, faith and image" [19, p. 270].

This main message of the Slavic Aeneid is wrapped in the subtext of the poem, appearing much as a parody, a grotesque travesty of the Virgilian heroic saga. The Ukrainian poet, a contemporary of Catherine the Great, must have been knowledgeable about her urban, military and cultural politics, largely influenced by her Italian advisers, and the crown joint Russo-Italian venture by the Black Sea - founding, developing and settling the Russian Carthage - the port of Odessa [10-11]. He witnessed the results of this policy and mass influx of foreigners, first mainly Italians, later - the Greeks, Germans, Swiss, French, Albanians, Bulgarians, Macedonians and Armenians to the New Russia [10-11]. This migration, and the preceding to it battles for Khadjibey, Ismail, Bendery and Yassy, revived the memories of Tan, Soldaiia and Khersones in the Crimea and the 12-14th centuries attempts of Genoese and Venetians, to penetrate Russia and include it into the European continent. By the end of the $18^{\text {th }}$ century, the relatively young Russian Empire, like many others in the past, required for the posterity her own poetic dignified inscription, and Kotliarevs'ky provided it with wit and wisdom. Aware of the marginal geographical, economic and cultural status of the Slavs but anticipating their rise, the poet, a Ukrainian by birth, sings a humorous ode to the Russians, destined to evolve into the modem Trojans and new Romans vis-à-vis Europe and their older Ukrainian relatives. A representative of the older Slavic tribe, he accepts with grace and dignity the fate of the Ukrainians to be ruled by the Russian Empire in the postNapoleonic era, seeing the rise and fall of every civilization as a historical inevitability and a universal law: "May it be whatever it may, and will it be whatever is the sacred will, man is not an angel - all are the same, born to perish at the end" [19, p. 72].

Kotliarevs'ky views the course of historical events as a chain of man-made circumstances, without the hysteria and trauma of the defeated. From the cultural heights of the $18^{\text {th }}$ century, the death of states, cultures, societies, kings, emperors and tzars appear to the poet as the most natural cycle of human development. He does not regard it as a tragedy. Moreover, the Ukrainian poet perceives it as an opportunity to assert the vitality of the New Europeans

Russia and Ukraine, both strangers to the Renaissance, have received their share of the Rabelaisian joy and pagan delight with the re-written, "re-lined" Ukrainian "Aeneid", which gracefully united the Trojans, Phoenicians, Greeks, Etruscans, Romans, Sicilians, Ligurians, Venetians and Florentines with their new cultural relatives - Russians and Ukrainians. With equal grace, Kotliarevs'ky assesses the Russian role in their intimate relationship with their Slavic brothers - the Ukrainians, acknowledging the role of the Russians in the battles with the Swedes (1709) near his native Poltava, with the Tartars (1785), or the Turks (1789). His Russians are the imaginary New Romans, carrying the torch of the Kievan Rus, the old New Troy, and related to the Ukrainians - the New Trojans of the region, whom they defeated and 
displaced in the course of history. The Cossacks are invented as the Slavic Etruscan shadows, omnipresent in pottery, music and attire. Etruscans are a successful metaphor for all the presently forgotten, but once significant, civilizations. Kotliarevs'ky's Ukrainian "Aeneid" poetically recalls the European antiquity to draw the analogy between the developmental pathways of different people and states. The Ukrainians are preserved as anthropological museum items, the cultural ancestors of the Russians. The defeat of the Cossacks, the absence of the independent state in the $18^{\text {th }}$ century Europe does not bother Kotliarevs'ky who possesses the ultimate inherited cultural capital - the Graeco-Roman legacy. The World Culture exists in the Word, attire, and song, regardless of who utters, wears or sings. Like Virgil, the Ukrainian poet is not concerned with ethnic purity, being aware of its actual impossibility. In fact, he mocks the ethnic or racial purity as a poet and the most qualified expert on the deeds of Venus, whose main preoccupation is Love and mixing between the loved. His Ukrainian Aeneas wears the attire, given by Didona, the Phoenician/Scythian princess, who, in turn, had stolen it from the dead conquered tribes. Kotliarevs'ky, like Virgil, reminds the Ukrainian readers of mingling and mixing, the actual essence of existence, the vitality and energetic progress. Troy, Carthage, Etruria, Rome, Scythia, Khersones, Soldaiia, Tan and many others are not dead, they continue to exist in Liguria and Sicily, modem Greece and young Russia. The death of Ukrainian language, if any, is as inevitable as the death of Latin in its own time, or as the death of Etruscan and Phoenicia centuries prior. The Ukrainian Dante anticipates some future rebirth of his culture, but, so far, he sings his ode to the Present.

\subsection{Ode to the Pagan Joy}

The Ukrainian Virgil and Dante, all in one, Kotliarevs'ky also sings, but not to arms. He sings to the delights of the ordinary Being in the world, the gastronomic and erotic, aesthetic and intellectual. He glorifies survival at the expense of those who fight. His Ukrainian Aeneas is the fortunate man, who escapes death and battle, a vagabond, the eternal migrant, the Trojan, who is destined to transplant but not to save Troy. The Ukrainian Aeneas is the burlesque of the Virgilian and Homeric proto-AENEAS. His poetic ancestors are Phoenicians and Trojans, Romans and Greeks, Scythians and Iranians, Turks and Genoese, Venetians and Cumans, Samnites and numerous other conquered and absorbed tribes, destined to be prior, to die, plant new seeds and regrow again anew. Sleep and rest, gastro and porno delight replace Homeric or Virgilian battles. The long ancient swords vanish to be replaced by the Ukrainian pirogy, borsch, cooked lamb and roasted pork. Kotliarevs'ky mocks the universal colonizing efforts, the blind reliance on force, stressing that the real survival is not in the military might but in physical fitness of the healthy, properly fed body. The wake ceremony in the honor of Aeneas' father Anchises, conducted in the typical Ukrainian peasant manner, is both a metaphor for the possible Trojan distant origins of these Southern Slavs and the ode to the Ukrainian vitality and survival. Instead of the sanitized ancestry lines proposed by the delusionary separatists, the Ukrainian national poet provokes a sophisticated discourse on the essential migration-mingling model as the universal mechanism for cultural production. Nor does he mourn the death of his unknown ancestors, offering instead a joyous celebration of the generations of the new Ukrainians, the reincarnated remnants of Troy, Carthage, Tyre, Rome, Etruria, Genoa and Venice. Through his Aeneas: "I wish to remember the old. Do 
you know, the Trojans, the Christians, that my father was Anchises, burned by drink who vanished like a winter fly [19, p. 38].

The Ukrainian Virgil-Dante celebrates with the Rebelaisian gusto the birth of the new strong, powerful and vital cultural species: "They put the fire outside, filling pots with meat. Dishes cooking, baking, five cauldrons with broth awaiting. Four with dumplings, six with borshch, countless sheep, chickens, ducks, geese grilled enough to feed the Empire [19, p. 38].

His paradise is in abundance of free food and drink, rivers of vodka and bathtubs of beer. His is the feast of the endlessly happy and lucky survivors, who no longer have any ties with the wisdom, toil and beauty of their obscure ancestors, who do not remember even their names, but Babylonia and Latium, Persia and Troy, Piraeus and Athens and even distant India are in them, in the attire of Aeneas' friends, Ukrainian kozacks, fated to die like many others in the past. The Ukrainian Virgil does not mourn any death of the old tribes and cultures. Old customs, old feuds, old castles and tunes, old tales and heroes - all are fated to transform into the Other again. It is the Slavic replica of Virgil and Vico, the idea of a cycle, anticipating the defeat of the Ukrainian, older segment of the Slavic civilization in favor of the more inclusive and outward looking Russian $18^{\text {th }}$ century culture [7, p. 121-27]. Neither Poltava, Kyiv, Kharkiv, nor Crimea are seen as the future New Naples or Genoa. The predicted cycle is turning towards the new Russian Empire and Kotliarevs'ky's commemoration of the old tribes is a prelude to the victory of the Russian Court and its new foreign and domestic politics. The poet- philosopher is a former loyal tsarist officer, who would eventually help to form battalions to fight the French in the war of 1812. He indirectly sings to the courage of the Russian soldiers, who had saved Ukrainians from the Swedes near his native Poltava (1709) and about to save again in the future battles against Napoleon. His message is that some tribes are destined to battle and conquer while others are fortunate to enjoy peace and celebrate daily life. Life within the Russian Empire, rather than in an independent state, is Kotliares'ky's message, which would eventually make him unpopular among the Ukrainian $19^{\text {th }}$ century romantics and $20^{\text {th }}$ century radical nationalists, destined to be overshadowed by the radical poet of independence, the alleged founder of the Ukrainian language and literature, Taras Shevchenko, despite the fact that the latter would never rise to the heights of the Ukrainian Virgil [6].

Kotliarevs'ky's existential philosophy and practicality would be taken even further by Nikolai Gogol, who would transport the Ukrainian culture beyond the borders of Poltava and Kyiv to St Petersburg and outside the frontiers of the Russian Empire, having translated it into Russian- the language of the New Rome. Following Kotliarevs'ky's poetic prophecy, Gogol would preserve the Ukrainian cultural essence in his Taras Bul'ba, Dead Souls, Inspector or Sorochinsky Fair [17, p. 15-16]. Gogol, included into the pantheon of the World Literature as a Russian, but not an Ukrainian, would be the living proof of Kotliarevs'ky's insightful historical vision. Locked within the Ukrainian pastoral borders, Kotliarevs'ky would remain largely unknown in the rest of the European cultural world, despite his Aeneid, while Gogol who dared to part with the older Slavic tongue was given a chance of the second cultural birth. Gogol would become the reincarnated Ukrainian bard, the traveling Aeneas who would reach the New Rome - St. Petersburg via the map, drawn up by the "Ukrainian Virgil."

Having skipped the Renaissance, the Slavic cultures have received their dosage of pagan 
enjoyment indirectly, via the intertextual relationships, re-readings and appropriations of the ancient literature, such as the Russian Aeneid by N. Osipov and Ukrainian one by Ivan Kotliarevs'ky. It is only through the comic re-readings, laughter and irony one may arrive at truth. "The truth is in the field of the comic," P. Volyns'ky quotes Nikolai Chemyshevs'ky who maintained that only comedy allows to dispense with the illusory identity and cognize one's true self [16, p. 152]. On the eve of the romantic infatuations with "roots," radically shaping the national, ethnic and religious identities and ultimate plunge into the regressive separatism, Kotliarevs'ky mocks the futile genealogical search, the anxiety of origins in his re-written Ukrainian Aeneid. Several centuries after Dante and Machiavelli, he mercilessly debunks the Judeo-Christian edifice, the Church and her tyrannical rule, depriving people from the enjoyment of Here and Now. Echoing the European thinkers of the Renaissance and the Enlightenment, Kotliarevs'ky questions the very concept of the religious, all European religions, their cultural and social usefulness. Drawing on the pre-Judeo-Christian GraecoLatin wisdom of the Romans, this Ukrainian poet establishes the cultural kinship of the Ukrainians with the rest of the Europeans and their indebtedness to the ancient past- the Phoenicia and Etruria, Troy and Greece, Babylonia and Persia, Egypt and Carthage, the true self is in admission of the Other in oneself. If Virgil and Dante poetically reconstructed the cultural and racial history of Europe, Kotliarevs'ky expanded the European family by adding to it the Ukrainians, the historically marginal Eastern Europeans into the imagined history of the continent.

\subsection{Perfecting Man}

Having poetically denounced the Church, the Ukrainian sage suggests to turn for moral and ethical guidance to the ancient European poets and philosophers. Having placed in hell the priests, government servants, bandits and crooks, Kotliarevs'ky preaches moderation, meditation and peace. A Masonic lodge member, the poet rethinks the usefulness of the Judeo-Christian religion and its place in society. He reminds his readers that it is possible to be honest, generous, moral and good without Christ and Christian dogmatism. His thinking is much akin to that of the Romans of the pre-Constantine era, whom Kotliarevs'ky praises for their wisdom and creativity: "Latin, the old was not a thug, and fighting was not his passion" [19, p. 146].

In fact, because the Romans were inclined to reach a solution by negotiation and compromise, they probably failed in the brutal reality of the first century AD when peace meant defeat. The "Ukrainian Virgil" mourns the defeat and death of the Roman Empire, the old noble lineage of the European civilization. Their failure, though a historic compromise in the strategy of avoiding the conflict is imagined by Kotliarev'ky as a plausible conscious act of submission to the new authoritarian monotheistic Christian Church, the offshoot of the Hebraic culture. The desire for peace among the impoverished and uneducated, and the intention to preserve stability for the geographically, ethnically and racially tom multilingual Empire, was the plausible explanation for Constantine's decision to legitimize Christianity. The Ukrainian rhyme carries the imagined account of this episode and the alleged Latin thinking: "Not at least am I to shed the blood [of Romans]. What is the origin of war? How could the thought possess you? When did my people enjoy the war?" [19, p. 146]. 
If the wise Roman law failed to unite the citizens and bring peace, then the Christian myth was tried to save the Latins. This profound poetic guess is behind Kotliarevs'ky's seemingly humorous picture of the ancient Ukrainian ancestor: "Oh, Muse of Parnassus, come to me at least for an hour, may your caress teach me" [19, p. 148].

When religion and Church fail to teach, civilize and perfect man, then the last resort is the poetic wisdom of Homer and Virgil, the offspring of the "wisest children of humanity". Kotliarevs'ky's profound assessment of the cultural and religious history of Europeans has the ultimate goal of including the marginal Europeans, formerly Byzantine, into the cultural family. He calls for respect of the ancients and their illustrious legacy. A very wise and serious message is behind his seemingly flippant travesty, the Ukrainian "vertep" comedy on the poetic debris of Homer and Virgil. His laughter is didactic in the true spirit of the Enlightenment. His educates his Ukrainian readers of the Aeneid about their complicated past, their mixed European blood and cultural belonging, carrying the profoundly appropriate and utterly modern message for the $20^{\text {th }}$ century delusionary age.

It is most regrettable and nearsighted that the future independent state of Ukraine would not grant Kotliarevs'ky the status of her national bard. Shevchenko's isolationist, separatist spirit would be much more compatible with the post-communist delusions and confusion. To embrace Kotliarevs'ky would have meant to acknowledge one's cultural youthfulness, wisdom and indebtedness to the European antiquity, which the myopic $20^{\text {th }}$ century would fail to do. Kotliarevs'ky laughingly destroys them with his $18^{\text {th }}$ century poetic judgement. His ideal perfect man is not a marginal ethnic, locked forever into his own myth, folklore, dance, and gastronomy. His is the man with a sense of history', memory, wisdom and humor , who may laugh easily at one's own cultural youthfulness, cowardice and naivete, who has the humility to learn and thus to become the cultural relative of the Western Europeans. It is neither a Christian, nor a Jew, neither a rich landowner, a businessman, nor a drunk beggar, but a curious voyager through life and times. Much like the Italian poet Pietro Metastacio (1698-1782), whom Kotliarevs'ky might have been inspired by, his image of life is the sea: “O, life, a stormy sea! Who survived you whole?" [19, p. 244].

He might have read Metastacio's Didona Abandonata (1724), so much akin to the entire project and message of the Ukrainian Aeneid.

Conclusions. In fact, the appropriation of the Greaco-Roman cultural legacy happens to be the uniform cultural route of all Europeans who at some point or another tend to return to the Greek Olympus and Roman Parnassus for inspiration by the glorious Other. For instance, Shakespeare's poetic universe is much Italian based, firmly rooted in the Roman history and life. Parma and Padua, Verona and Venice, Mantua and Florence, Ferrara and Florence are his numerous Italian points of historical reference. Shakespeare is the English challenge to Dante, Italy and the Graeco-Roman past. Aeschylus and Euripides, Aristophanes and Ovid, Solon and Terpander, Alcaeus and Sappho, Anacreon and Pindar, Plautus and Terence - all would be revived in Chaucer and Marlowe, Pope and Blake, Swift and Swinburne, Wordsworth and Byron. The "Russian Shakespeare" - Pushkin would regard Virgil as his mentor, as much as Anacreon or Hesiod, Ennius or Vigny, Chateaubriand or Byron. The inscription on the monument to William Shakespeare in Stratford-upon -Avon compares him to Socrates and Virgil, revealing the collective national anxiety and the imperial aspirations of the inhabitants 
of the British Isles. In awe of the Graeco-Roman antiquity, Alexander Pushkin composed a poem "The Monument" with the epigraph from Horatius' "Exegi monumentum," having predicted his own role in the Russian cultural history. No European nation could call itself complete without the communion with her cultural forefathers - Greece and Rome, or Italy as their cultural offspring. Pietro Pomponazzi (1462-1525) anticipates Spinosa and Kant; Giambattista Vico, who would apply Virgil to his philosophy of history, comes to the fore as the direct precursor of Kant, Hegel and Marx [15, p. 64]. D. H. Lawrence would abandon the muddy unconscious and stop pondering over the Freudian "id", turning his love towards the Etruscan tombs. The author of Women in Love, Sons and Lovers and the Lady Chatterlay's Lover, inspired by Florence and Genoa, Rome and Pisa, would fall in love with the Etruscans, seeing them as the cultural progenitors of the modem Italians: "Rome fell, and the Roman phenomenon with it. Italy today is far more Etruscan in its pulse, than Roman: it will always be so. The Etruscan element is like the grass of the field and the sprouting of com, in Italy: it will always be so" [3, p. 36].

Emulating the pathway of the Greeks and Trojans, Latins and Romans, and acknowledging one's kinship with them is the uniform cultural pattern of all Europeans, including the Ukrainians. The noble "aristocratic" cultural lineage happens to be the common source of the tribal anxiety and envy, raison-d-etre and impetus for life, inspiration and compass in the happy and successful voyage through life.

The European Union in the $21^{\text {st }}$ century would legitimize this quest, eliminating the genealogical cultural anxiety and traumatic memory. The endorsement of the shared cultural history and development, sameness of the sources of cultural nurturing, and recognition of Europeanness as a continental form of consciousness and identity would ultimately prevail over the modernist, separatist tantrums. Facing the challenge of the new barbarians, Europe would try to rebuild its Rome and reinvent its Mantua amidst the silence of the Muse and above the dormant post-modem Parnassus, out of the debris of the destroyed European civilization. Our voyage from Virgil, and Dante to Kotliarevs'ky is a humble opportunity of reminding the Universal, "what will always be so" - the eternal cycles of rebirth and renewal, the rebellions against the cultural forefathers and the desire to rebuild culture anew - would always stumble upon the legacy of the past.

\section{REFERENCES}

1. Conte G. B. "Contradiction in Virgil" / G. B. Conte. - The Alexander Lecture at the University of Toronto, October, 2003.

2. Jensen A. A. Perelytzovana Aeneida Kotliarevs'kogo / Aeneid with Changed Lining in Kotliarevs'ky/ A. A. Jensen - Peremysl : Keller and Son,1921.

3. Lawrence D.H. Sketches of Etruscan Places / D. H. Lawrence. - London : Cambridge Press, 1992.

4. Levi P. Virgil / P. Levi. - New York : St. Martin's Press, 1998.

5. Machiavelli N. History of Florence / N. Machiavelli. - Trans. by Hugo Albert Rennert. New York : Walter Dunn, 1901.

6. Makolkin A. Name, Hero, Icon: Semiotics of Nationalism / A. Makolkin. - Berlin : Mouton de Gruyter,1992. 
7. Makolkin A. Vico's Firstness, Secondness and Thirdness: The Common Essence of Nations as a Sign / A. Makolkin // Giambattista Vico and the Anglo-American Science / Ed. by M. Danesi. - Berlin : Mouton De Gruyter,1995. - P. 119-121.

8. Makolkin A. Anatomy of Heroism / A. Makolkin. - Ottawa : Legas,2000.

9. Makolkin A. The Genealogy of Our Present Moral Disarray / A. Makolkin. - Lewiston, NY : Edwin Mellen Press, 2000.

10. Makolkin A. A History of Odessa, the Last Italian Black Sea Colony / A. Makolkin. Lewiston, NY : Edwin Mellen Press, 2004.

11. Makolkin A. $19^{\text {th }}$ Century in Odessa. Italian Culture by the Black Sea / A. Makolkin. Lewiston, NY : Edwin Mellen Press, 2007.

12. Makolkin A. Phoenician Roots of European Civilization / A. Makolkin. - Toronto : Anik Press, 2016.

13. Mashkin N. Istoriia drevnego Rima [The History of Ancient Rome] / A. Makolkin. Moscow : Gospolitizdat, 1956.

14. Neborak V. Perechytana Eneida [Aeneid Revisited] / V. Neborak. - Lviv : Astron, 2001.

15. Prezzolini G. The Legacy of Italy / G. Prezzolini. - New York : S. Vanni, 1998.

16. Volyns'ky P. Ivan Kotliarevs'ky / P. Volyns'ky. - Kyiv : Dnipro, 1969.

17. Zalashka A. (ed.). Kotliarevs'ky v krytytsi [Kotliarevs'ky and critics] / A. Zalashka (ed). Kyiv : Vydavnytstvo Khudozhnioi. Literatury, 1959.

\section{SOURCES}

18. Dante A. The Divine Comedy / A. Dante. - Trans, by and with a Commentary by Ch. S. Singleton. - Princeto n: Princeton University Press, 1980.

19. Kotliarevs'ky I. Eneida [Aeneid] / I. Kotliarevs'ky. - Kyiv : Dnipro, 1968.

20. Virgil. Aeneid / Virgil. - Trans, by Allen Madelstam. - Berkeley, Ca : University of California Press, 1971. 


\title{
ЕНЕЙ, ДУХОВНИЙ БАТЬКО ВЕРГІЛІЯ, ДАНТЕ ТА КОТЛЯРЕВСЬКОГО
}

\author{
Анна Маколкін \\ Торонтський університет, Канада \\ anna.makolkin@utoronto.ca
}

Мета цієї порівняльної студії трьох поетів, розділених часом, мовами, етнічною приналежністю та історією, - визначити їхню спільну європейську культурну ідентичність та континентальну приналежність. У статті підкреслено європейськійсть Вергілія з Мантуї, Данте з Флоренції та Котляревського з Полтави, спільне коріння яких бере свій початок у греко-римській античності. Еней, легендарний гомерівський персонаж, стає їхною спільною культурно-поетичною основою, отже “духовним батьком".

Язичницька греко-римська минувшина є джерелом натхнення для пізньоримського автора етруського походження Вергілія, ренесансного поета Данте та українця-громадянина Російської імперії Івана Котляревського, і всі вони є продуктами “змішування та перемішування”, які поділяють спільну європейську культурну ідентичність. Мотив крові та спорідненості, тобто загального співпереживання за долю людства, перебуває у фокусі аналізу, адже ці поети вибудовують європейськість у змішуванні та перемішуванні замість надмірного вжитку окремішностей.

Ключові слова: античність, язичництво, світська культура, культурна ідентичність, колективна пам'ять, культурна власність, культурний родовід, симбіоз, цивілізований, дикун, цикл, культурні наставники. 